\title{
Carbon Footprints: Various Approaches to Clothing Care and Maintenance Practices Among Tertiary Students in Ghana
}

\author{
Joana Akweley Zanu ", Rebecca Lartey, Gloria Adablah \\ Department of Fashion Designing and Textiles Studies, Tamale Technical University, Tamale, Ghana \\ Email address: \\ adotey1985@gmail.com (J. A. Zanu), Rebaccalartey@yahoo.com (R. Lartey),gpadabla@gmail.com (G. Adablah) \\ ${ }^{*}$ Corresponding author
}

\section{To cite this article:}

Joana Akweley Zanu, Rebecca Lartey, Gloria Adablah. Carbon Footprints: Various Approaches to Clothing Care and Maintenance Practices Among Tertiary Students in Ghana. Science, Technology \& Public Policy. Vol. 2, No. 1, 2018, pp. 11-19. doi: 10.11648/j.stpp.20180201.13

Received: August 8, 2018; Accepted: August 20, 2018; Published: September 13, 2018

\begin{abstract}
The current study investigated the existing patterns of student laundry application. It distinguishes the environmental implications of these practices. Thus, the explanatory research design was adopted due to the nature of the study as there was the need to compare and analyse the responses from standardised questionnaires through the use of descriptive and inferential statistics which fit well into the explanatory survey design. This study hence adopted the quantitative methodology. The sample used for this study were tertiary students in Ghana. Convenience sampling method was used to select 150 students from four tertiary institutions and administered with questionnaires. The major findings of the study demonstrate that tertiary students are fully aware of the assertion that carbon footprint is something that leads to global warming and accepts that shaking, brushing and airing of clothes can be considered as an approach to clothing care and maintenance. They also appreciate that practising dry cleaning of clothes by the use of grease absorbents without the use of water should be considered as an approach to clothing care and maintenance. It was concluded that practicing dry cleaning of clothes by the use of grease absorbents without the use of water must be considered as an approach to clothing care and maintenance in tertiary institutions in Ghana.
\end{abstract}

Keywords: Carbon Footprints, Clothes, Greenhouse Gas, Detergents

\section{Introduction}

Climatic change is one of the numerous pressing issues confronting humanity. It is increasingly being acknowledged as a significant challenge. It is universally acknowledged that the greenhouse gas emissions triggered by humans are having a harmful effect on the environment. The most critical greenhouse gas, rising from human actions is carbon dioxide $\left(\mathrm{CO}_{2}\right)$. Although there are many gases present in the atmosphere, the most famous term frequently associated with these climatic changes include the Green House Gas (GHG). This is responsible for trapping the thermal radiation from the sun within the earth's atmosphere and leads to what is acknowledged as the greenhouse effect. The components of the GHG are water vapour $\left(\mathrm{H}_{2} \mathrm{O}\right)$, carbon dioxide $\left(\mathrm{CO}_{2}\right)$, methane $\left(\mathrm{CH}_{4}\right)$, nitrous oxide $\left(\mathrm{N}_{2} \mathrm{O}\right)$, ozone $\left(\mathrm{O}_{3}\right)$, and much more [1].

As pointed out by Huang et al., each gas has distinctive greenhouse consequences on a molecule-by-molecule basis. Methane has a considerable greenhouse effect than $\mathrm{CO}_{2}$ [2] . However, $\mathrm{CO}_{2}$ is found in far more substantial quantities in the atmosphere than methane. Water vapour is the most abundant component of the greenhouse effect, but its contribution is very insignificant when compared to $\mathrm{CO}_{2}$. Besides humans do not have enough control over water vapour as they produce over $\mathrm{CO}_{2}$ emissions. Hence, most climatic change reduction concentrates on $\mathrm{CO}_{2}$ emissions.

The term "carbon footprint" has grown in popularity over the past decade in response to the growing public consciousness of environmental matters and climate change. This term is now widely used throughout the media, government and commercial world. The popularity of this concept is intrinsically associated with concern about increasing levels of $\mathrm{CO}_{2}$ in the earth's atmosphere and the belief that rising concentrations of $\mathrm{CO}_{2}$ have and will continue to alter the earth's climate [3]. 
A way to track one's greenhouse gas emissions is to be aware of their carbon footprint. Carbon footprint is the entire volume of $\mathrm{CO}_{2}$ and other greenhouse gases discharged over the complete life cycle of a process or product. Environmental influences arise at each stage of the life cycle of a garment. The clothing industry has contributed to the global warming from the phase of raw material acquisition to the manufacturing of the garment, its distribution and transportation to stores and customers, then its use by the consumers and finally the disposal of the product after use [4].

Laundries discharge millions of gallons of effluent as hazardous toxic waste, full of detergents, bleach and other chemicals from washing clothes. Also, the presence of sulphur, naphthol, dyes, nitrates, acetic acid, chromium compounds, etc., collectively makes the effluent highly toxic. Other harmful chemicals present may be formaldehyde-based dye fixing agents, hydrocarbon-based softeners, and non-bio degradable dyeing compounds. The mill effluent is also frequently at a high temperature, both of which are incredibly damaging.

The colloidal matter present in dyes used for fabrics increases the turbidity and gives water a lousy appearance and foul odour. It averts the infiltration of sunshine essential for the process of photosynthesis [5]. These dyes conflict with the Oxygen transfer mechanism at the air-water interface. Depletion of evaporated oxygen in water is the most severe effect of laundry waste as dissolved oxygen is essential. This also hinders the self-purification process of water. Also, when this effluent is permitted to circulate in the fields, it clogs the orifices of the soil resulting in loss of soil fertility. The composition of soil becomes hardened, and the penetration of roots is restricted [6].

As inferred by Batra, the wastewater that flows in drains corrodes and incrassates the sewerage pipelines [7]. If permitted to flow in sewers and rivers it affects the quality of drinking water in hand pumps making it inappropriate for human consumption. This may also lead to leakage in drains increasing their maintenance cost. Such polluted water can be a breeding ground for bacteria and viruses. Carbon footprints of clothing care and maintenance among tertiary students is a cause of the significant amount of environmental degradation and human illnesses [8].

All the organic materials present in the wastewater from laundry are of immerse worry in water treatment since they react with several disinfectants particularly chlorine. Chemicals evaporate into the atmostphere, people breathe or they are absorbed through the skin and become allergic reactions. This is usually more than twice as carbon-intensive as generating heat from gas. All the above and more necessitates the need to analyze the carbon footprints of clothing care and maintenance practices among tertiary students in Ghana. Specifically, the study assessed student's knowledge of the concept of carbon footprints and explored the various approaches to clothing care and maintenance among tertiary students.

\section{Literature Review}

\subsection{Origins and Definition of the Carbon 'Footprint' Concept}

Planners first developed the application of the term "footprint" to describe the impact of human production or consumption activities at the University of British Columbia [9]. Wackernagel \& Rees describe an "ecological footprint" as an accounting instrument employed to estimate the resource consumption and waste absorption requirements of a designated human community or economy concerning a corresponding productive land area [9]. The environmental footprint theory is still extensively employed today as a resource management tool [10].

The term carbon footprint originated from the ecological footprint concept but in recent years has evolved into an idea in its own right. While a globally accepted definition of a carbon footprint is yet to exist, significant discernible variations between these phases are apparent. Overall, a carbon footprint focuses on processes and practices associated with the emission of $\mathrm{CO}_{2}$ (and other greenhouse gases). According to Growcom, this is in contrast to the larger range of ecological effects resulting from human acts comprised within the concept of an ecological footprint [11]. Growcom inferred that, while an ecological footprint is a ratio of the regenerative potential of the environment displayed in a corresponding area of fertile land, the majority of descriptions for a carbon footprint, measure a physical volume of carbon or equivalent gases emanating from defined activities [11]. The ensuring are some specific definitions of carbon footprints:

1) The carbon footprint measures the demand on biocapacity that arises from burning fossil fuels regarding the volume of forest area needed to segregate these $\mathrm{CO}_{2}$ emissions [10].

2) The term carbon footprint is generally applied to represent the total volume of $\mathrm{CO}_{2}$ and other greenhouse gas (GHG) emissions for which a person or institution is accountable. Footprints can further be calculated for events or products [12].

3) The carbon footprint is a measure of the particular cumulative amount of $\mathrm{CO}_{2}$ emissions that are directly and indirectly produced by an action or is accumulated over the life stages of a product [13].

4) $\mathrm{A}$ measure of the amount of $\mathrm{CO}_{2}$ emitted through the combustion of fossil fuels; in the instance of an institution or business, it is the $\mathrm{CO}_{2}$ emissions that occur as a result of their daily operations; in the case of a person or household, it is the $\mathrm{CO}_{2}$ emissions that result from their everyday activities; for a product or service, it involves extra life-cycle $\mathrm{CO}_{2}$ emissions along the supply chain; for materials, it is a measure of the embodied $\mathrm{CO}_{2}$ emissions ascertained through life cycle evaluation [14].

5) A measure of the amount of $\mathrm{CO}_{2}$ emitted through the combustion of fossil fuels. A carbon footprint is usually expressed as tons of $\mathrm{CO}_{2}$ or tons of carbon 
emitted, generally on a yearly basis [15].

6) This term relates to the amount of productive land (forest) needed to sequester (remove) the equal amount of GHGs that an organization emits [16]. The total amount of $\mathrm{CO}_{2}$ and other greenhouse gases, emitted over the full life cycle of a product or service [17].

\subsection{Carbon Footprints and Clothing in General}

The primary carbon footprint impacts related to apparel production and utilization include resource depletion from the consumption of water, fossil fuels and energy, chemical and greenhouse gas emission, wastewater effluent and solid waste output [18]. Allwood et al., asserted that conventional cotton products require extensive use of water and toxic chemicals, that can damage human health and the environment [18]. These chemicals according to Khan \& Islam, are used in the forms of pesticides and in dyeing, finishing and washing process, and are further released into wastewater, causing water pollution problem and threatening to the lives in these waters [19].

Furthermore, the manufacturing process of fabrics and clothing generates a significant amount of solid waste. During the clothing utilization stage, laundering often relates to water consumption and chemical use. Additionally, a considerable amount of energy is used for drying and ironing. Finally, the majority of clothing is sent to the landfills instead of being reused or recycled [20]. Take a cotton made T-shirt, for instance, a $250 \mathrm{~g}$ cotton T-shirt requires $1.7 \mathrm{~kg}$ of fossil fuel for electricity used in washing, drying and ironing, and further causes $4 \mathrm{~kg} \mathrm{CO}_{2}$ emissions. Also, 125g of laundry detergent will be released into the water while washing the Tshirt, and $450 \mathrm{~g}$ of waste will be sent to the landfills after use [18].

Chancel infer that the concept of carbon footprint in the apparel and textile industry satisfies the present needs for fashion but without compromising the ability of future generations to meet their own fashion needs [21]. Thus, Meyer defined sustainable apparel products as the garments which are designed, manufactured, transported, consumed or recycled with the materials and methods that reflect environmental and social concerns [22]. Different practices have been used in caring for and maintaining clothing, aimed at minimizing the negative impacts on the environment and maximizing the benefits to humans and society [23].

In the context of clothing use (care and maintenance) phase comprise washing, drying and ironing, washing alone requires material inputs of water, cleansing agent and potentially fabric conditioner. Drying requires no inputs of materials. All activities of the use phase require inputs of energy, water and detergent [24]. Although clothes are typically washed and dried as mixed loads, each garment is likely to require a different quantity of water, (hot or cold) detergent, etc. to be washed or dried, depending on its weight and the composition of fibers and the physical properties of these fibers. However, there is considerable uncertainty in quantifying these differences. Therefore, in common with previous studies, such as electricity used for washing, drying and ironing was allocated to clothing on a mass basis, rather than differentiated by fiber type [2].

\subsection{Clothing Care and Maintenance Practices}

Clothing care and maintenance practices refer to the resources used to take care of an apparel product during its useful life, such as laundering, bleaching, drying and ironing among others [23]. Previous literature has found that the most significant carbon footprint occurred during the consumer care and maintenance phase $[18,26]$. For instance, according to a blouse life cycle study, many the environmental effects such as energy consumption, solid waste, carbon dioxide, and biological oxygen demand were aroused from the clothing care and maintenance stage [27]. Furthermore, when evaluated from the perspective of clothing life cycle assessment, their care and maintenance period is the most energy demanding [28].

Laitala \& Boks infers that laundering alone accounts for $82 \%$ of the energy use during the clothing life cycle [28]. Likewise, Allwood et al., inferred that $60 \%$ of the energy consumption in a cotton T-shirt was associated with washing and drying [18]. A study on the life cycle of a pair of Levi's jeans showed that $23 \%$ of the water was used and $37 \%$ of the carbon dioxide was emitted during the consumer care and maintenance phase [29]. Consequently, eco-labels and low impact instructions are provided by many apparel companies. For instance, Levi Strauss $\&$ Co. passed the message of "Wash less, wash with cold, line dry, and donate when no longer needed" to consumers on all global products' care tags [30].

In the Higg Brand Module, criteria related to the product care include design for durability and longevity and product care communication. The Higg Index gives 14 points for the brands that have enhanced product durability and maximized product useful life and gives 12 points for those who have made low impact care instructions publicly available and easily accessible for consumers. Another aspect of the consumer care and maintenance phase is clothing repair. As note by Fletcher, many fast fashion products on today's market cannot last long due to poor quality [31]. At the same time, the low price encourages consumers to replace products quickly, causing additional environmental effects from production and disposal stages.

However, some apparel companies such as Patagonia, Flint and Tinder, and Tom Cridland are making efforts in keeping and repairing their old products. For example, Patagonia provides a step-by-step repair guide on their websites and offers repair service for the products consumers sent back to them [32]. Tom Cridland offers 30 years guarantee sweatshirt and T-shirt to its consumers [33]. If consumers' sweatshirt or T-shirt is damaged within the 30-year warranty, Tom Cridland will repair it for free. In the Higg Brand Module, criteria related to product repair include reparability design standards and repair service communication. The Higg Index gives 18 points for the brands that have maximized product repairable and upgradable features when designing products and gives 12 points to those who have communicated their repair program with consumers. 
The way individuals take care of clothing has an enormous negative impact on the environment. Unnecessarily frequent washing, high washing temperature, excessive use of detergents and tumble drying would shorten clothing longevity [18]. Taking laundering, for instance, technological improvements in washing machines and the appearance of environmentally friendly detergents have reduced the total carbon footprints impact per wash. However, the increasing washing frequencies and a number of clothing individuals own, have impeded these improved technologies [34].

A study on patrons laundry habits conducted in Norway demonstrates that the majority of the participants measured dosage based on eyes. Only $12 \%$ of the participants followed detergent usage instructions and used the measuring cup [28]. A study on laundry practices in Germany indicated that consumers did not vary detergent dosage based on the type of garments, soiling level and the amount of laundering [35]. Besides, as specified by Laitala \& Klepp, washing machines tend to be underloaded if consumers were washing with different sorting categories [36].

Individuals care and maintenance behavior not only relates to the development of technology but also refers to the accessibility of information and willingness to change [37]. Almost all clothing is attached to the information such as size, country of origin, fiber content and cares instructions, presented in the forms of labels or hang tags [36]. Although brands intend to make care and maintenance information publicly available and easily accessible for buyers, the level of understanding and following these instructions by consumers were relatively low [38]. It was also found that consumers were confused with the various labels, which inhibited them to use it correctly [39].

Additionally, previous literature revealed that patrons were reluctant to follow the information on care labels but relied on their experience and knowledge instead [36, 40]. Regarding clothing maintenance, Ryttinger \& Holtmaat mentioned that individuals repair behavior associated with various factors including the value of garments, the availability of materials and repair skills [41]. Previous research has shown that buyers had limited skills on clothing maintenance, which inhibited the acceptance of care and maintenance practices through the utilization stage [34, 28], 42].

Equally, Laitala \& Boks discovered that buyers were more likely to repair simple tasks: sewing on a button (73\%), fixing an unraveled seam (55\%), patching clothes $(31 \%)$, darning garments $(27 \%)$, and adjusting trouser length (26\%) [28]. However, most consumers were unable to solve advanced repairs such as replacing a zipper. Besides, consumers preferred to dispose of or replace with a new garment than to repair the old one since most of the clothing today is affordable leading to carbon footprints [41].

\subsection{Laundering Behavior of People in General}

Laundry habits, which are linked to cleanliness, are influenced by culture, society, and morals and are continually changing [28]. Cleanliness is not specific to time and place. It can be measured by the absence of dirt or bacteria and is an outcome of religious, social, or practical reasons [43]. Social competition often drives cleanliness and associated with values like success, acceptance, and happiness. Cleanliness and, in particular, personal hygiene is also associated with health [44]. Since the 1950s, the dirtiness of clothing has been considered something that comes from within the body, such as sweat or body oils, when it was previously noted as coming from an external source referring to stains, dirt, and dust.

Clothing was originally meant to keep the body clean and dirt free, however, now the body is seen as a cause of dirty clothing. This change of paradigm has caused an increased focus on odor as unclean rather than visible stains which is also now the norm for determining when to change and wash clothing [44]. Standards of cleanliness can actually be a cause of internal conflict, as many individuals have trouble understanding social cues and feedback in regards to cleanliness and end up overcompensating in their cleaning behaviors [45].

With the rise of cleanliness standards, showering and laundering have increased more than ever in the past several decades. It is likely that the most substantial positive effect for clothing carbon footprints is through behavioral change [37]. Altering peoples' behavior can benefit the earth and, in turn, the human population. Unfortunately, environmental and social benefits are not substantial enough reasons for the average person to change their behaviors when compared with individual consumer wants. It is argued that many people are not concerned with the environmental impact of the increased cleanliness standards because they are not knowledgeable of the problems associated with it [46]. However, there are obvious links between the global carbon footprint issues and individual behavior shown through domestic energy consumption.

\section{Methodology}

In this study, both descriptive and exploratory research design was chosen to investigate the effects of clothing care and maintenance practices on carbon footprints among tertiary students in Ghana. A research design according to Cohen et al., is the systematic plans and procedures a researcher develops to study a scientific problem [47]. This study adopted the quantitative methodology. Quantitative research as inferred by Leavy provides clear statistical data for inference and supports larger sample sizes which translate to more generalizability over the population being studied [48]. Again, Creswel, notes that one benefit of the quantitative approach is that the outcomes are valid, reliable and generalizable to a bigger population [49]. The quantitative approach was selected based on the nature of the study and its methodological foundation. This investigation attempts to explore the everyday life of tertiary students behaviour in relation to their approaches to clothing care and maintenance in their natural setting. The sample used for this study were tertiary students in Ghana. Convenience sampling was used to select 150 students from various institutions and administered with questionnaires. 


\section{Findings and Discussions}

\subsection{Student's Understanding of Carbon Footprints and Clothing Care and Maintenance}

Table 1. Students' understanding of carbon footprints.

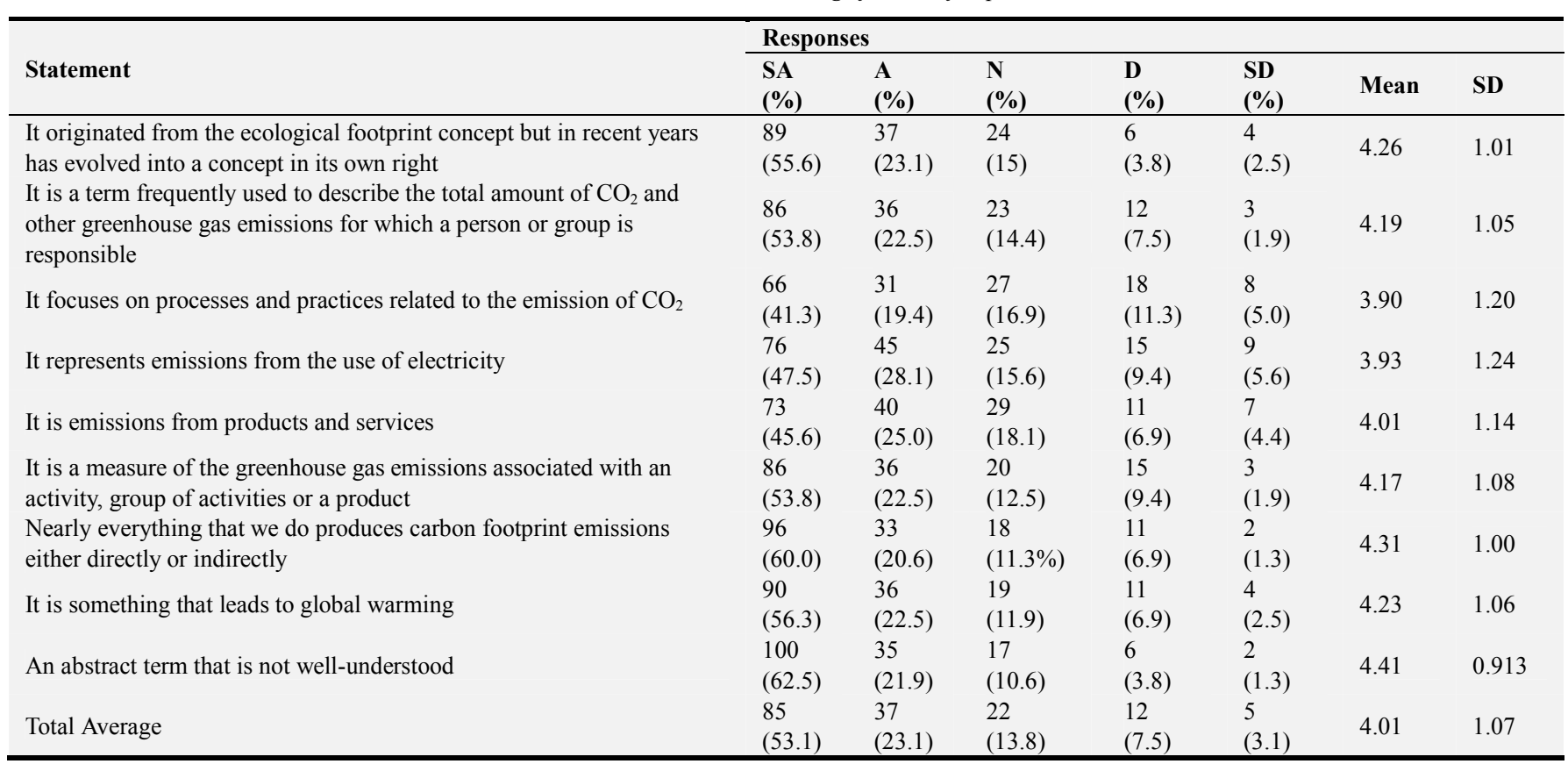

$1=$ strongly disagree 2 =disagree $3=$ neutral $4=$ agree $5=$ strongly agree

Table 1 presents respondents' views on their understanding of Carbon footprints in relation to clothing care and maintenance. The responses were computed in frequencies and percentages with conclusions made on their means and standard deviations. In summary, the responses were aggregated to assess the general trend of tertiary student's understanding of carbon footprints. From the responses as being shown in table 1 , it could be observed that on the average 85 respondents constituting 53.1\% strongly agreed to various definitions and assumption of carbon footprints reflecting their understanding of the concept. Meanwhile, 37 representing $23.1 \%$ of the respondents agreed with 22 respondents also constituting $13.8 \%$ chose to remain neutral, 12 representing $7.5 \%$ disagreed whiles 5 representing $3.1 \%$ strongly disagreed. The mean score for the distribution was 4.01 representing a general agreement from a majority of the respondents. From the responses, it can, therefore, be concluded that tertiary students demonstrated an in-depth understanding of the concept of carbon footprints and how their everyday activities influence global warming through carbon footprinting.

\subsection{Approaches to Clothing Care and Maintenance Among Tertiary Students}

Table 2. Approaches to clothing care and maintenance.

\begin{tabular}{|c|c|c|c|c|c|c|c|}
\hline \multirow[b]{2}{*}{ Statement } & \multicolumn{7}{|c|}{ Responses } \\
\hline & $\begin{array}{l}\text { SA } \\
(\%)\end{array}$ & $\begin{array}{l}\text { A } \\
(\%)\end{array}$ & $\begin{array}{l}\mathbf{N} \\
(\%)\end{array}$ & $\begin{array}{l}\text { D } \\
(\%)\end{array}$ & $\begin{array}{l}\text { SD } \\
(\%)\end{array}$ & Mean & SD \\
\hline $\begin{array}{l}\text { Read care labels which provide basic information about the } \\
\text { garment, relative to care and maintenance instructions }\end{array}$ & $\begin{array}{l}74 \\
(46.3)\end{array}$ & $\begin{array}{l}52 \\
(32.5)\end{array}$ & $29(18.1)$ & $\begin{array}{l}2 \\
(1.3)\end{array}$ & $\begin{array}{l}3 \\
(1.9)\end{array}$ & 4.20 & .910 \\
\hline Shaking, brushing and airing of clothes & $\begin{array}{l}70 \\
(43.8)\end{array}$ & $\begin{array}{l}47 \\
(29.4)\end{array}$ & $\begin{array}{l}32 \\
(20)\end{array}$ & $\begin{array}{l}10 \\
(6.3)\end{array}$ & $\begin{array}{l}1 \\
(.63)\end{array}$ & 4.09 & .970 \\
\hline Laundering/washing of clothes & $\begin{array}{l}84 \\
(52.5)\end{array}$ & $\begin{array}{l}32 \\
(20)\end{array}$ & $\begin{array}{l}31 \\
(19.4)\end{array}$ & $\begin{array}{l}10 \\
(6.3)\end{array}$ & $\begin{array}{l}2 \\
(1.3)\end{array}$ & 4.17 & 1.03 \\
\hline $\begin{array}{l}\text { Dry cleaning/washing by using solvents and/or grease absorbents } \\
\text { without the use of water }\end{array}$ & $\begin{array}{l}74 \\
(46.3)\end{array}$ & $\begin{array}{l}52 \\
(32.5)\end{array}$ & $\begin{array}{l}25 \\
(15.6)\end{array}$ & $\begin{array}{l}7 \\
(4.4)\end{array}$ & $\begin{array}{l}2 \\
(1.3)\end{array}$ & 4.18 & .937 \\
\hline $\begin{array}{l}\text { Dray wash garments inside out to minimize surface abrasion and } \\
\text { aid in maintaining the surface appearance }\end{array}$ & $\begin{array}{l}21 \\
(13.1)\end{array}$ & $\begin{array}{l}80 \\
(50.0)\end{array}$ & $\begin{array}{l}13 \\
(8.1)\end{array}$ & $\begin{array}{l}42 \\
(26.3)\end{array}$ & $\begin{array}{l}4 \\
(2.5)\end{array}$ & 4.14 & 1.08 \\
\hline Iron/pressing after each wash & $\begin{array}{l}19 \\
(11.9)\end{array}$ & $\begin{array}{l}90 \\
(56.3)\end{array}$ & $\begin{array}{l}9 \\
(5.6)\end{array}$ & $\begin{array}{l}24 \\
(15)\end{array}$ & $\begin{array}{l}18 \\
(11.3)\end{array}$ & 4.21 & .99 \\
\hline $\begin{array}{l}\text { Mend damaged garments e.g. Replace buttons, repair hems, repair } \\
\text { seems, patch holes etc. }\end{array}$ & $\begin{array}{l}28 \\
(17.5)\end{array}$ & $\begin{array}{l}79 \\
(49.4)\end{array}$ & $\begin{array}{l}11 \\
(6.9)\end{array}$ & $\begin{array}{l}24 \\
(15.0)\end{array}$ & $\begin{array}{l}18 \\
(11.3)\end{array}$ & 4.28 & .92 \\
\hline
\end{tabular}




\begin{tabular}{|c|c|c|c|c|c|c|c|}
\hline \multirow[b]{2}{*}{ Statement } & \multicolumn{7}{|c|}{ Responses } \\
\hline & $\begin{array}{l}\text { SA } \\
(\%)\end{array}$ & $\begin{array}{l}A \\
(\%)\end{array}$ & $\begin{array}{l}N \\
(\%)\end{array}$ & $\begin{array}{l}D \\
(\%)\end{array}$ & $\begin{array}{l}\text { SD } \\
(\%)\end{array}$ & Mean & SD \\
\hline Neatly fold and store clothe appropriately & $\begin{array}{l}16 \\
(10.0)\end{array}$ & $\begin{array}{l}43 \\
(26.9)\end{array}$ & $\begin{array}{l}27 \\
(16.9)\end{array}$ & $\begin{array}{l}48 \\
(30.0)\end{array}$ & $\begin{array}{l}26 \\
(16.3)\end{array}$ & 4.30 & .92 \\
\hline Hang up/put away clothing after wear & $\begin{array}{l}19 \\
(11.9)\end{array}$ & $\begin{array}{l}77 \\
(48.1)\end{array}$ & $\begin{array}{l}7 \\
(4.4)\end{array}$ & $\begin{array}{l}31 \\
(19.4)\end{array}$ & $\begin{array}{l}26 \\
(16.3)\end{array}$ & 4.11 & 1.10 \\
\hline Total Average & $80(50 \%)$ & $43(26.9)$ & $\begin{array}{l}26 \\
(16.25)\end{array}$ & $\begin{array}{l}8 \\
(5)\end{array}$ & $\begin{array}{l}3 \\
(1.8)\end{array}$ & 4.18 & 1.01 \\
\hline
\end{tabular}

$1=$ strongly disagree $2=$ disagree $3=$ neutral $4=$ agree $5=$ strongly agree

Table 2 gives a presentation of respondents' responses on the approaches to clothing care and maintenance they practice. A summary of the responses shows that 74 representing $46.3 \%$ of the respondents strongly agreed. While 52 representing $32.5 \%$ agreed, 29 representing $18.1 \%$ were neutral, two representing $1.3 \%$ disagreed whiles three respondents representing $1.9 \%$ strongly disagreed that they read care labels which provide basic information about the garment, relative to care and maintenance instructions should be regarded as an approach to clothing care and maintenance. That notwithstanding the mean and standard deviation statistics $(\mathrm{M}=4.20, \mathrm{SD}=.9910)$ shows that responses were towards the agreement end of the rating scale.

Again, from the responses, it could be observed that about half $(n=70,43.8 \%)$ of the respondents, strongly agreed that they shake, brush and air clothes to ensure clothes are cared for and maintained. Additionally, $(n=47$, $29.4 \%$ ) of the respondents agreed whiles 32 being $30 \%$ remained neutral and 10 respondents, making up $6.3 \%$ disagreed whiles only one respondent representing $6 \%$ strongly disagreed. With a mean statistic of $(\mathrm{M}=4.09$, $\pm \mathrm{SD}=.970$ ) it can be concluded that most of the responses were towards the agreement side of the response scale implying that the tertiary students accept that shaking, brushing and airing of clothes can be considered as an approach to clothing care and maintenance.

Furthermore, a summary of the responses revealed that 84 respondents representing $52.5 \%$ strongly agreed to practice laundering/washing of clothes, 32 representing 20\% agreed, 31 representing $19.4 \%$ remained neutral, 10 representing $6.3 \%$ disagreed whiles only two representing $1.3 \%$ strongly disagreed $(M=4.17, S D=1.032)$. From the results, it can be settled that laundering or washing of clothes is considered as an approach to clothing care and maintenance.

Again, the responses show that nearly half $(n=74$, $46.3 \%$ ) of the respondents agreed strongly that practising dry cleaning/washing by using solvents and/or grease absorbents without the use of water. While 52 representing $32.5 \%$ agreed, 25 representing $15.6 \%$ were neutral, seven representing $4.4 \%$ disagreed whiles 2 respondents representing $1.3 \%$ strongly disagreed $(\mathrm{M}=4.18, \pm \mathrm{SD}=.937)$. From the results, it can be determined that the respondents appreciate that practising dry cleaning of clothes by the use of grease absorbents without the use of water should be considered as an approach to clothing care and maintenance.
Table 3. Kendal's Coefficient of concordance on approaches to clothing care \& maintenance.

\begin{tabular}{|c|c|c|}
\hline Ranks & $\mu$ & Rank \\
\hline Neatly fold and store clothe appropriately & 5.34 & $1 \mathrm{st}$ \\
\hline $\begin{array}{l}\text { Mend damaged garments, e.g., replace buttons, } \\
\text { repair hems, repair seams, patch holes etc. }\end{array}$ & 5.23 & 2 nd \\
\hline Laundering/washing of clothes & 5.08 & $3 \mathrm{rd}$ \\
\hline $\begin{array}{l}\text { Read care labels which provide basic information } \\
\text { about the garment, relative to care and maintenance } \\
\text { instructions }\end{array}$ & 5.03 & 4 th \\
\hline Iron/pressing after each wash & 5.03 & 5 th \\
\hline $\begin{array}{l}\text { Dry cleaning/cleaning by using solvents and/or } \\
\text { grease absorbents without the use of water }\end{array}$ & 4.94 & 6 th \\
\hline $\begin{array}{l}\text { Dry wash garments inside out to minimize surface } \\
\text { abrasion and aid in maintaining the surface } \\
\text { appearance }\end{array}$ & 4.9 & 7 th \\
\hline Hang up/put away clothing after wear & 4.83 & 8 th \\
\hline Shaking, brushing and airing of clothes & 4.62 & 9th \\
\hline
\end{tabular}

Kendall's Wa $=0.84, \chi 2=13.915, \mathrm{df}=8, \mathrm{Sig}=.001$

In Table 3 using Kendal's mean ranking coefficients of concordance, it could be observed that the most adopted approach to clothing care and maintenance employed by the respondents is neatly folding and storing their clothes appropriately with Kendal's mean statistic of 5.34 being the highest ranked item hence ranked $1^{\text {st }}$. Additionally, the mending of damaged garments example replacing buttons, repair hems, seams, patch holes and among others obtained the second highest mean score with 5.23 hence ranked the $2^{\text {nd }}$ most adopted approach to clothing care and maintenance. Laundering/washing of clothes also obtained the $3^{\text {rd }}$ highest mean score suggesting that it is the third most adopted approach to clothing care and maintenance. However, hanging up/put away clothing after wear and Shaking, brushing and airing of clothes obtained mean scores of $(\mathrm{M}=4.83)$ and $(\mathrm{M}=4.62)$; hence was ranked as the lowest approaches adopted by the respondents as their approaches to clothing care and maintenance.

Kendall's Coefficient of Concordance on the approaches to clothing care and maintenance adopted by the tertiary students. Kendal coefficient was calculated on the means of the following as they apply to the approaches. Respondents $\chi^{2}(8$, $\mathrm{N}=160)=13.915$, $\mathrm{p}>0.001$ did differ much in their responses to their approaches to clothing care and maintenance, and a Kendal coefficient value $(\mathrm{W}=0.84$ ) indicates a more unanimity among the various respondents in their responses.

In summary, exactly half of the respondents, $50 \%$ strongly agreed to adopting the above-stated approaches to clothing 
care and maintenance, $26.9 \%$ agree. Whiles $16.25 \%$ remained neutral, representing $5 \%$ disagreed whiles the remaining three respondents representing $1.8 \%$ strongly disagreed on a mean score of 4.18 ; which indicates an agreement to various assertions by the majority of the respondents. The trend of the responses implies that the tertiary students agreed mostly on most of the approaches to clothing care and maintenance.

\subsection{Carbon Footprints Associated with Clothing Care and Maintenance Practices Among Tertiary Students}

Table 4. Carbon footprints of clothing care and maintenance practices.

\begin{tabular}{|c|c|c|c|c|c|}
\hline Descriptive Statistics & $\mathbf{N}$ & Min. & Max. & Mean & \pm SD \\
\hline Laundry accounts for about one-quarter of the carbon footprint of clothing & 160 & 0 & 5 & 3.82 & 1.22 \\
\hline Not following clothing care instructions in labels carefully and thoroughly & 160 & 0 & 5 & 4.23 & .98 \\
\hline Ineffective laundry machines & 160 & 0 & 5 & 4.06 & 1.13 \\
\hline Heating up wash water & 160 & 0 & 5 & 4.21 & 1.07 \\
\hline Not using detergents that work in cold water & 160 & 0 & 5 & 4.08 & .99 \\
\hline Usage of harmful detergents and bleach & 160 & 0 & 5 & 4.06 & 1.10 \\
\hline Total average & 160 & 0 & 5 & 4.07 & 1.08 \\
\hline
\end{tabular}

$1=$ strongly disagree 2 =disagree $3=$ neutral $4=$ agree $5=$ strongly agree

Table 4 gives a presentation of the means and standard deviations of respondents' views of carbon footprints of clothing care and maintenance practices. From table 4, it could be observed that the majority of the respondents agreed that laundry accounts for about one-quarter of the carbon footprint of clothing $(\mathrm{M}=3.882, \mathrm{SD}=1.21)$, not following clothing care instructions in labels carefully and thoroughly $(\mathrm{M}=4.23, \mathrm{SD}=.984$, ineffective laundry machines $(\mathrm{M}=4.06$, $\mathrm{SD}=1.137)$, heating up wash water $(\mathrm{M}=4.21, \mathrm{SD}=1.078)$, not using detergents that work in cold water $(\mathrm{M}=4.08, \mathrm{SD}=.997)$, and usage of harmful detergents and bleach $(\mathrm{M}=4.06$, $\mathrm{SD}=1.100$ ) are some of the approaches to clothing care and maintenance that impacts the environment. From the trend of the responses, it can be concluded that the tertiary students are aware of the fact that laundry and the failure to clothing care instructions in labels account for about one-quarter of the carbon footprint.

\section{Conclusions}

Domestic laundry which is the task of getting 'dirty' clothing and other items clean again and ready for use is most often taken for granted, yet it is a fundamental feature of everyday life. It also carries significant environmental burdens. Clothing care and maintenance practices among tertiary students' environmental impacts occurs from machine, fabric and detergent manufacture and disposal, water usage, distribution and discharge, as well as domestic energy usage (for washing, drying, and ironing). Environmental influences arise through the development of laundry products and devices. Nevertheless, the 'use phase' is an environmental hot spot.

Consequntly, steps must be taken to enhance the energy and water performance of washing machines, and to enhance the environmental performance of surfactants and other laundry products, such that the results of households cleaning their clothes are decreased. These technological reforms have operated hand in hand with measures that actively attempt to shape how people care and maintain their garment. This may be cast against the more common trend for governments and institutions to respond to the challenges of anthropogenic climate change by advancing interventions in the processes by which people acquire, appropriate and value goods and services.

\section{References}

[1] Matthews, H. S., Hendrickson, C. T. \& Weber, C. L. (2008). The Importance of Carbon Footprint Estimation Boundaries. Environmental Science \& Technology 42, 5839-5842.

[2] Huang, Y. A., Weber, C. L. \& Matthews, H. S. (2009). Categorization of Scope Emissions for Streamlined Enterprise Carbon Footprinting. Environmental Science \& Technology 43, 8509-8515.

[3] IPCC (2007). Climate change 2007 synthesis report summary for policymakers, Intergovernmental Panel on Climate Change, http://www.ipcc.ch/pdf/assessmentreport/ar4/syr/ar4_syr_spm.pdf

[4] Agarwal, R. (2010). Development of software to calculate the carbon footprint of any garment style in apparel manufacturing (Graduation project). Technova. National Institute of Fashion Technology (NIFT), Hyderabad, India. http://www.scribd.com/doc/49557088/technova-2010

[5] Hazardous Substance Research Centers/South and South-west Outreach Program (2005). Environmental hazards of the textile industry. Environmental Update \#24, Business Week.

[6] Rugrungruang, F. Chua, B. H., \& Low, S. C. (2009). Development of product carbon footprint assessment: a step towards sustainability for Singapore manufacturing industry. SIM Tech technical reports, 10(2), 112-117.

[7] Batra, S. (2013). Assessment of Carbon Footprint and Water Footprint of Apparel Manufacturing Units under OGTC. Poster presented at the 9th International Conference on Apparel \& Home Textiles "Creative Thinking". New Delhi, India: Okhla Garment Textile Cluster.

[8] United Kingdom Faculty of Public Health (2008), Sustaining a Healthy Future Taking Action on Climate Change. London. January 2008. http://www.fph.org.uk

[9] Wackernagel, M \& Rees, W, E. (1996). Our Ecological Footprint: reducing human impact on the earth, New Society Publishers, Gabriola Island, Canada. 
[10] Global Footprint Network (2007). Ecological Footprint: Overview, Global Footprint Network, http://www.footprintnetwork.org/gfn sub.php?content=footpri nt_overview

[11] Growcom, A. J. (2008). What is a Carbon Footprint? An overview of definitions and methodologies. Vegetable Industry Carbon Footprint Scoping Study - Discussion Paper. Sydney: Horticulture Australia Ltd.

[12] Carbon Trust (2011). Clothing. London: International Carbon Flows.

[13] Wiedmann, T. \& Minx, J. (2007). A definition of 'carbon footprint', ISA Research and Consulting, Durham, United Kingdom, http://www.censa.org.uk/reports.html

[14] Carbon N Zero (2008). Glossary of commonly used terms, Landcare Research. http://www.carbonzero.co.nz/glossary.asp

[15] TreeVestors 2008, Green glossary, TreeVestors $\mathrm{http}: / /$ www.treevestors.com/?section=A_Greener_Life\&page $=$ Green_Glossary

[16] Triplepundit 2008, Carbon Market Terminology Deciphered by Climate Check, Triplepundit. http://www.triplepundit.com/pages/carbonmarket $\neg$ terminology-deci-003010.php

[17] MCI (2008). MCi's go green glossary http://www.mcicoach.com/gogreen/greenGlossary.htm

[18] Allwood, J. M., Laursen, S. E., de Rodriguez, C. M., \& Bocken, N. M. (2006). Well dressed? The present and future sustainability of clothing and textiles in the United Kingdom. Cambridge, UK: University of Cambridge, Institute for Manufacturing.

[19] Khan, M. M. R., \& Islam, M. M. (2015). Materials and manufacturing environmental sustainability evaluation of apparel product: knitted T-shirt case study. Textiles and Clothing Sustainability, 1(1), 1-12.

[20] Goworek, H. (2011). Social and environmental sustainability in the clothing industry: a case study of a fair-trade retailer. Social Responsibility Journal, 7(1), 74-86.

[21] Chancel L (2014) Are younger generations higher carbon emitters than their elders? Inequalities, generations and $\mathrm{CO}_{2}$ emissions in France and in the USA. Ecological Economics 100: 195-207.

[22] Meyer, A. (2001). What's İn İt For the Customers? Successfully Marketing Green Clothes. Business Strategy and The Environment, 10 (5), 317-330.

[23] Moon, K. K. L., Youn, C., Chang, J. M., \& Yeung, A. W. H. (2013). Product design scenarios for energy saving: A case study of fashion apparel. International Journal of Production Economics, 146(2), 392-401.

[24] Thomas, B., Fishwick, M., Joyce, J. \& van Santen, A. (2012). A Carbon Footprint for UK Clothing and Opportunities for Savings. Final Report, UK: Environmental Resources Management Limited.

[25] Bio Intelligence service (2009, Unpublished) EC-funded IMPRO project on "Environmental improvement potential of textiles" (final report 2009, unpublished).

[26] Chen, H. L., \& Burns, L. D. (2006). Environmental analysis of textile products. Clothing and Textiles Research Journal, 24(3), 248-261.
[27] Fletcher, K. (2008) Sustainable Fashion and Textiles: Design Journeys. Earthscan, London, and Sterling.

[28] Laitala, K., \& Boks, C. (2012). Sustainable clothing design: use matters. Journal of Design Research 14, 10(1-2), 121-139.

[29] Badore, M. (2015, March 17). Levi's wants you to help lower the impact of jeans. Retrieved from http://www.treehugger.com/corporateresponsibility/leviswants-you-help-lower-impact-jeans.html.

[30] Vestel, L. B. (2009). With New Care Tags, Levi Strauss Aims to Reduce Its Footprint. The New York Times. http://green.blogs.nytimes.com/2009/10/27/with-newconsumer-care-tagslevi-strauss-aims-to-reduce-its-carbonfootprint/?_r=0.95.

[31] Fletcher, K. (2010). Slow fashion: an invitation for systems change. Fashion Practice, 2(2), 259- 265.

[32] Becker, T. (2014, April 4). Worn wear: Initiative for sustainability by Patagonia. http://www.ispo.com/en/companies/id_77743408/worn-wearinitiative-for sustainability-by-patagonia.html

[33] Liecke, A. D. (2015, June 17). This sweatshirt will last 30 years, guaranteed. http://www.esquire.com/style/mensfashion/news/a35775/the30-year-sweatshirt/

[34] Fisher, T., Cooper, T., Woodward, S., Hiller, A., \& Goworek, H. (2008). Public understanding of sustainable clothing: a report to the Department for Environment, Food and Rural Affairs. London, UK: Department for Environment, Food and Rural Affairs.

[35] Kruschwitz, A., Karle, A., Schmitz, A., \& Stamminger, R. (2014). Consumer laundry practices in Germany. International Journal of Consumer Studies, 38(3), 265-277.

[36] Laitala, K., \& Klepp, I. G. (2013). Environmental and ethical perceptions related to clothing labels among Norwegian consumers. Textile and Apparel Research Journal of Textile and Apparel, 17(1), 50-58.

[37] Laitala, K., Boks, C., \& Klepp, I. G. (2011). Potential for environmental improvements in laundering. International Journal of Consumer Studies, 35(2), 254-264.

[38] Thøgersen, J. (2000). Psychological determinants of paying attention to eco-labels in purchase decisions: Model development and multinational validation. Journal of Consumer Policy, 23(3), 285-313.

[39] Hanss, D., \& Böhm, G. (2012). Sustainability seen from the perspective of consumers. International Journal of Consumer Studies, 36(6), 678-687.

[40] El-Dessouki, H. A. (2015). A survey on knowledge about care label on garments by Residents in Egypt. Life Science Journal, 12(3), 49-53.

[41] Ryttinger, L., \& Holtmaat, K. (2014). The work on sustainability in the use and disposal stage of a garment's life cycle - The perspective of three Swedish clothing companies. Unpublished master's thesis, The Swedish School of Textiles, University of Borås, Borås, Sweden.

[42] Norum, P. S. (2013). Examination of Apparel Maintenance Skills and Practices: Implications for Sustainable Clothing Consumption. Fam. Consum. Sci. Res. J., 42, 124-137. 
[43] Klepp, I. G. (2007). Patched, louse-ridden, tattered: Clean and dirty clothes. Textile: The Journal of Cloth and Culture, 5(3), 254-275.

[44] Gram-Hanssen, K. (2007). Teenage consumption of cleanliness: How to make it sustainable? Sustainability: Science, practice \& policy, 3(2), 15-23

[45] Jack, T. (2013). Nobody was dirty: Intervening in inconspicuous consumption of laundry routines. Journal of Consumer Culture, 13(3), 406-421.

[46] Jarvi, P., \& Paloviita, A. (2007). Product-related information for sustainable use of laundry detergents in Finnish households. Journal of Cleaner Production, 15(7), 681-689.
[47] Cohen, L., Manion, L., \& Morrison, K. (2011). Research Methods in Education 7th (ed.). New York: Routledge.

[48] Leavy, P. (2017). Research Design: Quantitative, Qualitative, Mixed Methods, Arts-Based, and Community-Based Participatory Research Approaches. Guilford Press.

[49] Creswell, R. (2014). Research design: qualitative, quantitative, and mixed methods approaches. USA: Sage Publications. 